\title{
FASHION AND COMMODIFICATION: AN ANALYSIS ON THE GLOBAL PHENOMENON OF SUPREME
}

\author{
Winda Eka Pahla Ayuningtyas \\ e-mail:winda.eka.pahla@mail.ugm.ac.id \\ Galant Nanta Adhitya \\ Universitas Respati Yogyakarta \\ e-mail: galant.nanta@ respati.ac.id
}

\begin{abstract}
Globalization is the global information spread and people interconnectivity. It is driven by technological developments in transportation and communication, removing cultural boundaries among nations. Cultural differences are increasingly less tangible and visible in all cultural products, including in fashion. Due to globalization, fashion brands that originate in a certain country can open stores across multiple continents. The invention of the Internet further widens their accessibility by consumers in any part of the world. However, globalization also brings an affordability gap between the upper and the lower classes. Nonetheless, fashion brands can also take advantage of this economic difference in appealing to their consumers. One of those brands is Supreme. Founded in 1994, it became the most sought-after hypebeast brand among street-fashion enthusiasts worldwide. How do they do it in less than 30 years is interesting to analyze. To answer this objective, this article is conducted from the cultural studies standpoint and the case study method. There are three formulas of positioning it adopts in order to grow globally: (1) the commodification African-American community, (2) the use of celebrity endorsement, and (3) the hype of limited-edition releases. Supreme sells oversized streetwear, heavily influenced by Hip-hop culture, a music genre rooted in the lives of African Americans. The brand makes use of celebrities, especially rappers, to endorse its clothes and accessories. It also continually makes headlines by releasing limited-edition products as well as collaborating with well-known figures and brands.
\end{abstract}

Keywords: commodification; hypebeast brand; transnationalism; streetwear fashion; Supreme

DOI $\quad$ : https://doi.org/10.22146/rubikon.v8i2.69692

Available at https://jurnal.ugm.ac.id/rubikon/article/view/69692

This work is licensed under a Creative Commons Attribution-ShareAlike 4.0 International License 


\section{INTRODUCTION}

In general terminology, globalization is the global spread of information as well as global interconnectivity. It is a phenomenon of time experienced by all counties around the world since the middle of the $20^{\text {th }}$ century. Transportation and communication technologies remove the boundaries among countries. The public can easily access content from other countries through various media platforms.

Furthermore, Freedman (1999, p. 156) and Woods (2000, p. 78) define globalization as a set of various quantitative and qualitative developments. It ranges from a dramatic increase in international transactions, especially in finance, to the international and spatial reorganization of production. It thus can be seen from the global harmonization of tastes and standards, liberalization, deregulation, privatization, the arrival of new information technologies, the global diffusion of information, values, and ideas, massive population transfers, trends towards a universal world culture, and the spread of a worldwide preference for democracy.

Consequently, globalization has also caused the spread of products and jobs across national borders and cultures, affecting all vital sectors. As stated by Giddens (1990, p. $364)$, it refers to the intensified global-scale social relations that connect locality with globality. What happens at the local stage shapes and is shaped by events in other hemispheres and vice versa. Globalization has different effects on the economy, politics, environment, and culture with different intensities.

Concerning culture, cultural globalization greatly influences a country's identity. Cultural globalization is the spread of ideas, meanings, and values in certain ways to nations across the globe and their citizens. In most cases, it is characterized by shared consumption of cultural products through the media. Its process thus depends on the speed and ease of access to information and communication flows.

Undoubtedly, globalization is an extraordinary and valuable, yet frightening and destructive occurrence. These contradicting effects can happen simultaneously and rapidly. It allows developed countries, as the source of globalization (Adhitya \& Wulandari, 2020, p. 187). This advantage then enables them to successfully influence the culture of the developing countries.

Inevitably, developed countries are culturally synonymous with western qualities. It is because they are the main controllers and drivers of international communication. As a result, developing countries are becoming more and more identical to white-centric characteristics. Cultural gaps among them are increasingly less tangible and visible. This erosion can be seen in all cultural products, especially fashion.

Fashion was one of the first industries to went global. As it is closely intertwined with lifestyle, the effects of globalization in the worldwide free-trade sector are felt in the fashion industry. Fashion brands originated in a country open stores across multiple continents. The invention of the Internet further widens their accessibility.

However, the damaging impacts of globalization are apparent in the fashion industry. According to Grusky (2014, p. 47), one main distinguishing feature of the fashion industry is its ability to differentiate between 
different social classes. The affordability gap in fashion consumption between the lower and upper classes causes social differentiation. Nonetheless, fashion brands can also take advantage of this difference in appealing to their consumers. The exclusivity and luxury of high-end fashion brands become a magnet for fashionista enthusiasts to gravitate towards. One of the brands to do so in targeting their consumers and pricing their products is Supreme.

Supreme is a fashion brand founded by James Jebbia in New York City in April 1994. Categorized as a streetwear brand, it initially only released $\mathrm{T}$-shirts. It soon expanded to designing hoodies, sweatshirts, sweatpants, shoes, bags, hats, jewelry, and skate-related products. Targeting the youth generation, it is now considered cool and popular. The youth's interest in the brand is not only visible on its physical retails but also on its online presence.

Supreme fans make use of the Internet to create their own community. Countless social media platforms, such as Instagram and Twitter, and websites are solely dedicated to the brand. A few of Supreme's most notable communities in cyberspace are a website addressed www.supremecommunity.com, an Instagram account named @SupCommunity, and an iPhone app called Supreme Community. Their activities range from discussing the brand and reselling their collection. They also talk about leaks on the brand's upcoming releases and collaborations as they prepare to snatch every last piece of its new arrivals.

This monumental success makes it categorized as a 'hypebeast' brand. Derived from the streetwear culture, hype beast is defined as slang for people obsessed, or 'beast', with everything kinship, or 'hype' (Beltran, 2018). The most vivid hype-beast characteristic is seen through their appearance. One of their signature styles is wearing pieces by a particular brand with its logo from head to toe. They always dress up their appearance in order to steal people's attention and stand out from the crowd. The obsession of the hypebeast community towards Supreme places it among the top 10 fashion brands of 2019 by the biggest hypebeast community website, www.hypebeast.com (Ho, 2019).

In less than its 30-year span, Supreme has been put on the same level as Gucci, Balenciaga and Dior. This rise is remarkable, as the established high-end brands have been around for more than a century. It has also been deemed a "legendary global status" (Sullivan, 2017). A question then comes to mind, how do they do it?. As a company, Supreme is said to have a different approach from other fashion brands. They thus always make headlines around the world from time to time. The brand itself and how it achieves such notoriety are interesting to analyze.

In analyzing this objective, the standpoint of cultural studies is used in this article. According to Fiske (1990, p. ii), cultural studies is the study of culture, its processes, practice, meaning and significance in various contexts, especially of popular culture. Cultural studies position all knowledge with the eclectic method, including knowledge integrated with culture, marking practice, representation, discourse, authority, articulation, text, reading, and consumption. In cultural studies, culture is considered a commodity. This commodification sees cultures for either their exchange values or sign-exchange values. A certain culture and its characteristics are thus being commodified in 
order to gain profit through purchases (Tyson, 2006, p. 62).

The consumers who purchase commodified cultural products are seen as active agents. Although the production of popular culture is in the hands of transnational capitalist companies, meaning that the products are constantly produced, changed, and regulated by the cultural gatekeepers, they are consumed by consumers who impassively make decisions. Their desire for commodities might manifest into a need that can never be fully gratified. Therefore, cultural studies assume that there is no need to lament and romanticize traditional culture and actively engage the audience in the international market (Barker, 2004).

Furthermore, the consumers' consumption drives an economic system based on the production and circulation of commodities (Jenkins, 2010, p. 965). Commodification is then examined regarding their relation to power and how it affects various cultural, socio-political, economic, scientific and legal conditions. The power held by the producers of commodified culture is heightened due to globalization with how it spreads and interconnects production, distribution, and consumption by the help of technologies across the world. Mann (2013, p. 11) also emphasizes that globalization involves the extension of distinct ideological, military, and political power relations from developed to developing countries. The state of interactions, communications and exchanges, the complexity and size of the networks involved, and the sheer volume of trades give multinational companies that operate and market across the globe a quadruple profit.
At its core, globalization refers to the universalization of the world system, including consumers' consumption. Its aim is for people all around the world to purchase the same commodified cultural products. The consumption of the commodified culture and its characteristics from one country to another generates uniformity (Safril, 2015, p. 50). This cultural globalization then leads to exchanging the norms, values, customs, and habits, damaging those of local culture due to the penetration of foreign culture (Sztompka, 2007, p. 108).

The global popularity of Supreme that penetrates globally is analyzed using a case study method. It is a strategy and an empirical inquiry investigating phenomena within their real-life context. The method is based on an in-depth investigation of an individual, group, or event to explore the causes of underlying principles. Yin (1994, p. 9) explains that the variety in the field of interest, the distinctive need for case study research arises out of the desire to understand complex social phenomena. Usually done in a field setting, it gives the opportunity to focus on a case and retain its holistic and real-world perspective, such as when studying individual life cycles, small group behavior, organizational and managerial processes, international relations and maturation of industries.

In addition, the primary data are from Supreme advertisements on its website www.supremenewyork.com and Instagram @ supremenewyork. These sources are chosen because they are directly managed by Supreme, signifying how the brand wants to be perceived by its consumers and the general public. The collected data are in the form of photos and screenshots. Meanwhile, the secondary data are gathered from journals, 
articles, and videos from reputable sources. This methodology is employed to discover the formula of positioning it adopts to grow globally and the driving factors contributing to it.

\section{DISCUSSION}

Supreme is one of the first streetwear brands to emerge in the fashion scene. From a small shop in the SoHo neighborhood, Manhattan, Supreme has manifested into a global fashion powerhouse. Staggering price tags on its comfortable clothes and casual accessories label it a luxury streetwear brand. However, instead of decreasing their enthusiasm, consumers worldwide are even more drawn to spend their money on its products. The expensiveness adds to the exclusivity of the brand because not every fan can purchase their products.

Besides this sales and marketing strategy in pricing, other formulas successfully taking Supreme into the stratospheric status it is today. After vigilant observation of cyber channels, there are three other carefully calculated formulas Supreme employs that can also be discovered. They are its commodification of the African-American community, its use of celebrity endorsement, and its hype of limited-edition releases.

\section{The Commodification of the African- American Community}

Cultural commodification is defined as an act of turning culture and/or its elements into a sellable commodity. When carried out by a member outside of that culture, it can either be understood as appreciation or appropriation. Cultural appreciation is thought of as a way to respectfully preserve a certain culture from being abandoned by its people, whereas cultural appropriation is deemed a deed to shamelessly gain profit or humor by taking advantage or making fun of the said culture (Holmes, 2016).

Cultural commodification can be found not only in contrasting cultures from across the globe. Both cultures can co-exist in the same society. People of the dominant culture often commodify less recognized subcultures. It can be seen in the case of Supreme.

Supreme was not meant to be a fashion brand. It was first created as a shop catering to the blooming New York skate crowd (Houston \& Fennell 2021). In the decades prior to the 1990s, skateboarding was a niche sport. Skaters and those interested in the subculture were their initial target consumers. The shop sold skateboards, spare parts and gears from established skate brands. Conveniently located with iconic skate spots, such as the Astor Place cube and the Brooklyn Banks nearby, it saw a moderate feat.

What took it to succeed internationally was when Supreme was shifted to be the fashion brand. However, cultural commodification can be intensely felt in the brand's success. Jebbia, who had neither design education nor experience, appointed a team of five designers, namely Brendon Babenzien, Geoff Heath, and Augie Galan. They decided to release a more street-style aesthetic as he saw the subculture as a promising business opportunity.

The first collection released consisted of "three T-shirts: one featuring an image of Robert de Niro from Taxi Driver, another showcasing a photo of a skater with an afro, and one with the store's much coveted box logo" (Takanashi, 2020). Henceforth, skaters and skate enthusiasts throughout the US have 
been seen wearing one (Brewer, 2021). Graphic t-shirts have been a staple in the brand's releases ever since.
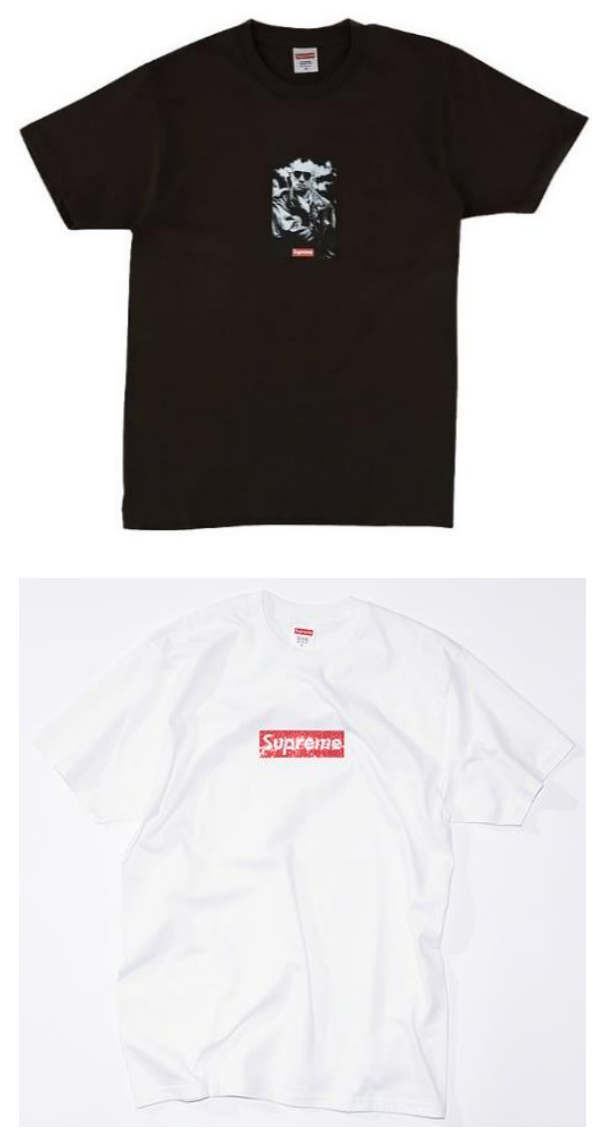

Figure $1 \& 2$. Supreme Graphic T-shirts

Street fashion is "indisputably associated" with Hip-hop, the music that stemmed from the lives of African Americans. Both cultural products are deemed the "area where keeping it real is held in high regard" (Cochrane, 2017). Over the years, as the genre acquires more popularity from the general American audience in the 1990s, so does Supreme. With the world getting more globalized each day, the more the brand is recognized globally.

Furthermore, Supreme's commodification of the African-American community can also be seen from the cutting of its clothes. The brand opts for baggy clothes. The reasons are to give freedom for skaters to move as well as offer protection upon falling. This choice is indifferent to other types of sports involving intricate bodily movements. For example, figure skaters and gymnasts are clad in skin-tight clothing, as the extra fabric will restrict their movement. Meanwhile, the assumption of its protection is arguable because its tops are made of light cotton.
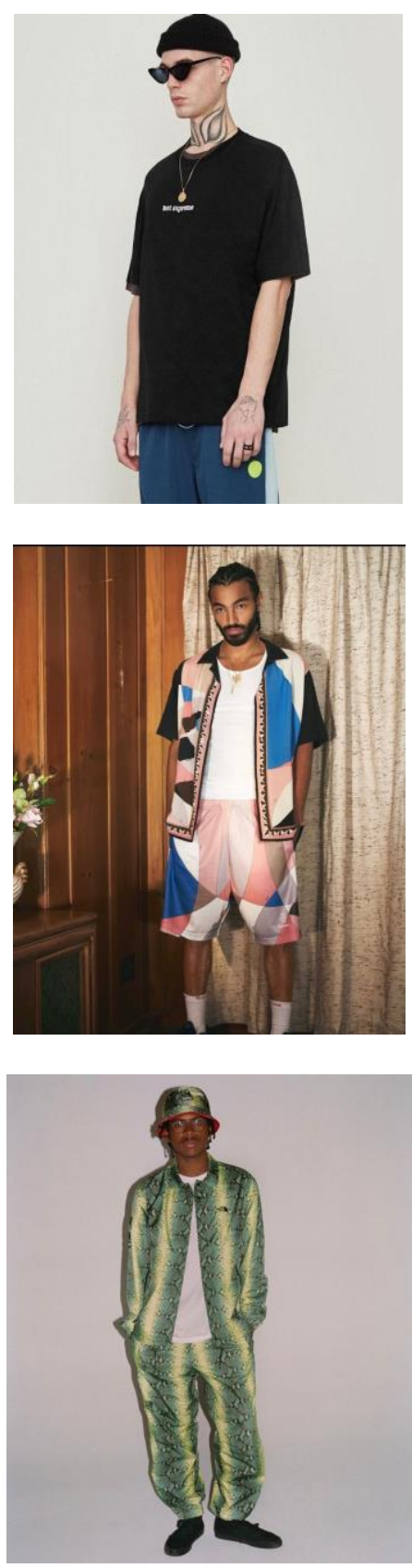

Figure 3, 4 \& 5. Supreme Oversized Clothes 
Besides the branded shirts and T-shirts, its pants also use baggy cuttings. Both skate shorts and cargo pants have become its main designs, alongside hoodies and tracksuits. Moreover, the level of bagginess Supreme apparels are designed deserves to be paid attention to. Sizing the brand uses diverts significantly from the standard of the US size guide, resulting in oversized clothes. Oversize clothing is entangled with the AfricanAmerican community.

Coming off of slavery and segregation, most African-American families were averagely below the poverty line. Besides food and housing, clothing was another basic need difficult to attain. Most of them relied on clothes donation, both from charity institutions, e.g., Goodwill, and their own relatives. Therefore, hand-me-downs were common in African-American households. As the clothes given were of larger fits, they became too big when worn by the younger ones.

Throughout the 1990s to 2000s, oversized clothing became a huge trend. Numerous fashion brands, especially streetwear ones, began adopting it in their collections. Unarguably, Supreme is the most successful brand in doing so. Ranging from top to bottom, Supreme never skips oversized pieces from their releasees every season.

Supreme's commodification of the African-American community can be perceived as oversized streetwear is closely associated with Hip-hop. Looking at the people behind the brand, Jebbia, a white man, can be considered to take advantage of African-American characteristics for his own financial gains. He and his brand commodify the remain of racial disparity for the sake of economic success.

\section{The Use of Celebrity Endorsement}

Among other high-end fashion brands that have been around for centuries, Supreme's birth pales in comparison. However, since the last two decades, the brand has been catching up to them. Today, it is often put alongside or even in direct competition with them. One of the most significant ways for Supreme to do so is by celebrity endorsement.

Endorsement is a public declaration of approval or support from a well-known figure to someone or something. It was initially applied in the field of politics indicating backing for candidates or policies. The term then became widely employed in the realm of marketing. According to U.S. Federal Trade Commission or FTC (2009):

an endorsement means any advertising message (including verbal statements, demonstrations, or depictions of the name, signature, likeness or other identifying personal characteristics of an individual or the name or seal of an organization) that consumers are likely to believe reflects the opinions, beliefs, findings, or experiences of a party other than the sponsoring advertiser, even if the views expressed by that party are identical to those of the sponsoring advertiser.

Over the years, researches have shown that this marketing technique gives favorable results in sales directly.

Instead of rolling celebrity endorsement the traditional ways, such as TV, magazine and billboard ads, Supreme uses famous celebrities to endorse its products in the realm of social media, by the likes of Instagram, Twitter and Snapchat. They are seen posting Supreme products for their millions of 
followers on their social media pages to see. One of the celebrities whose endorsements have significantly strengthened Supreme image throughout the global scale is Kanye West.

West is an award-winning rapper, songwriter and producer. $\mathrm{He}$ is also recently recognized as a fashion designer and entrepreneur. Prior to releasing his own subbrand with Adidas named Yeezy, he has frequently been making appearances clad in Supreme products on highly-publicized occasions, including award ceremonies, album releases and family events. His social media posts are not simply personal entries sharing his day-to-day activities but strategically calculated larger-than-life images.
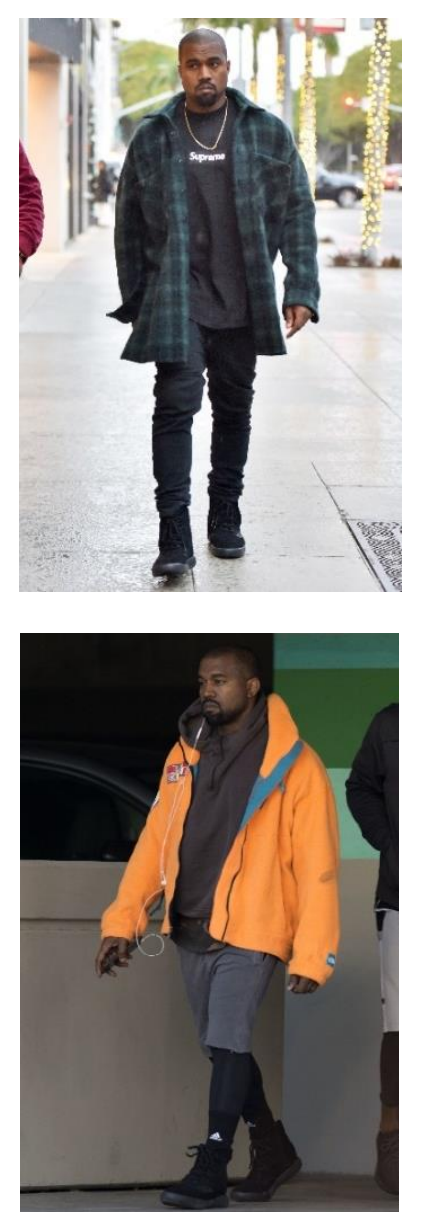

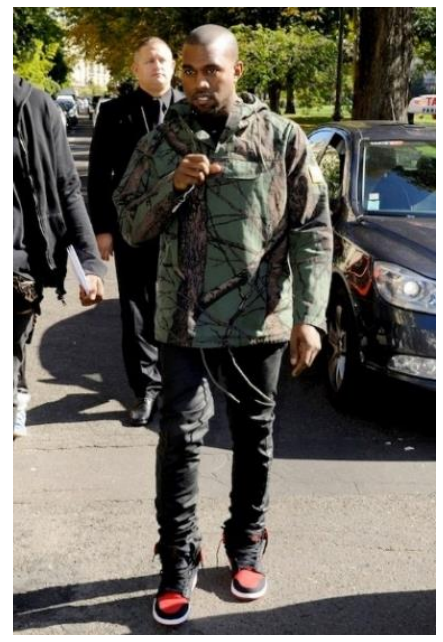

Figure $6,7 \& 8$. Kanye West wearing Supreme

West is vastly influential to Supreme's rise to a global street style brand that it is dubbed as 'Kanye Effect'. The moment he is seen wearing Supreme, his fans instantly idolize the brand as well. It is because the more consumers are being exposed to a brand, the more likely they are going to develop an association with it (Waring, 2018). West has successfully earned the brand a high degree of recognition, trust, respect or awareness. Deshmukh (in Schiffer, 2017) states that he is "to be seen as not just a face of the brand, but integral to the brand itself".

Furthermore, as an African-American hip-hop star, West's role in globalizing Supreme reinforces that the brand commodifies the community. As stated by Markman (in Schiffer, 2017), "high-end fashion designers used to turn their nose up at hip-hop; now, they have to respect the influence [it wields], whether they like it or not". In addition, it is not only West who heavily endorses Supreme. Other AfricanAmerican hip-hop stars can also be easily spotted uploading what appears to be endorsements for the brand. To name a few are A \$AP Rocky, Travis Scott and Jaden Smith. 

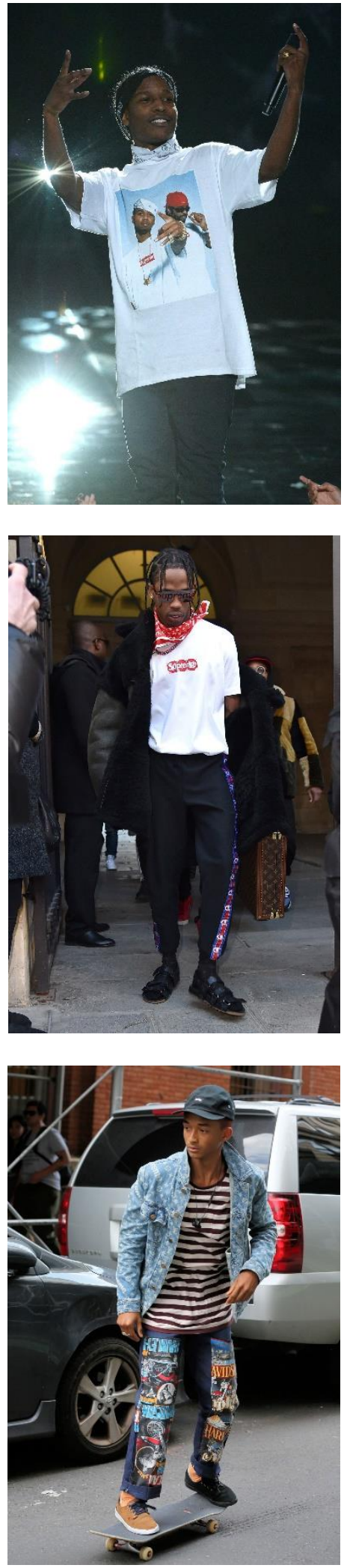

Figure. 9, $10 \&$ 11. African-American Hip-hop Stars
It is also worth noting that Supreme never officially names any celebrities, particularly African-American hip-hop stars, as their brand ambassadors. However, the endorsements from the current AfricanAmerican famous personalities have cemented Supreme as a central part of the hip-hop scene, despite having no roots from the AfricanAmerican culture. Such covert advertising has the ability to be relatable to a wide variety of people than ordinary advertising does. The ads then become some sort of aspiration, far beyond merely a promotion.

\section{The Hype of Limited Edition Releases}

Besides commodifying AfricanAmerican characteristics and using hip-hop star endorsement, Supreme makes a name for itself with a different approach. Other brands keep filling their offline and online stores with an unlimited stock of products in selling as many as they can to boost revenue. On the contrary, Supreme is known globally for releasing a limited amount of products. As explained by Jebbia (in O'Brien, 2009):

We've never really been supply-demand anyway. It's not like when we're making something, we make only six of them. But if we can sell 600, I make 400. We've always been like that - at least for the past seven or eight years. For every season, we put in a lot of work to try to create exciting stuff.

Supreme has been shaping itself to be exclusive. The brand does not rely on how many products are sold, but rather on how much each product is sold for. On the one hand, it limits its scope of consumers. On the other hand, it appeals to the upper-class demographic.

The hype of its limited-edition can be identified from its first collection that 
consisted of only three t-shirts (Takanashi, 2020). Subsequently, it created a regulation for future release, called 'one-limit-per-style'. It means that if a shirt comes out in black, red, and gray, each consumer can only get it on color. Therefore, if they want it in other colors, they need to get two other people to stand in line to get it for them.

On top of that rule, not everyone can come to the Supreme stores at their convenience. While other fashion brands continuously open their stores in every big city worldwide, Supreme insists on having a handful of stores. Until recently, there are only 13 Supreme stores around the world (Mahadevan, 2021). Moreover, in order to get the chance to step into its stores, as described by Magnaye (in Houston \& Fennell, 2021):

you go to the Supreme website, you enter your basic information: your name, email, phone number, and credit-card number. Then, they'll send you a text later in the day to let you know if you've been selected to stand in line. Then on Wednesday, they'll send you a text telling you the time and store to report to. And on Thursday, you go to the store at the time that you're given.

Supreme brings these layers of exclusivity to its online store. Its website does not actually sell its products. It only shows the date and time of release for its new collections. However, as soon as they are released, they are sold out instantly. The website then goes to its 'coming soon' mode.

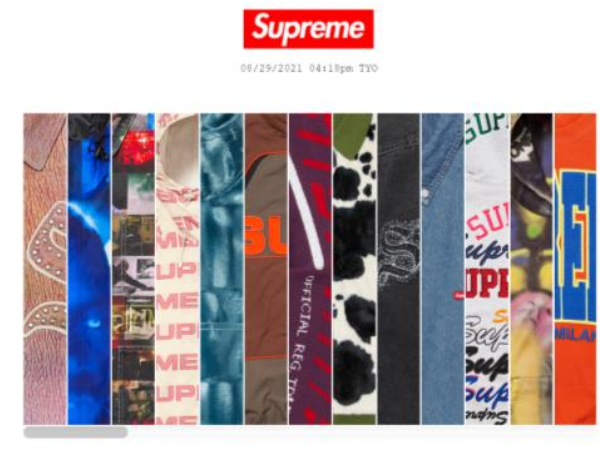

Figure 12. Supreme Website

Additionally, Supreme enhances its level of exclusivity by collaborating with other fashion brands. From one collection to another, it has collaborated both with other street-style and high-end luxury brands. Supreme's brand collaborators include Supreme are BAPE, Spalding, Rimowa, Nike, Louis Vuitton, Jean-Paul Gautier, Vans, The North Face, Comme de Garcons, Levi's, Timberland, Lacoste, Dover Street Market and Stone Island (Wilson, 2017).

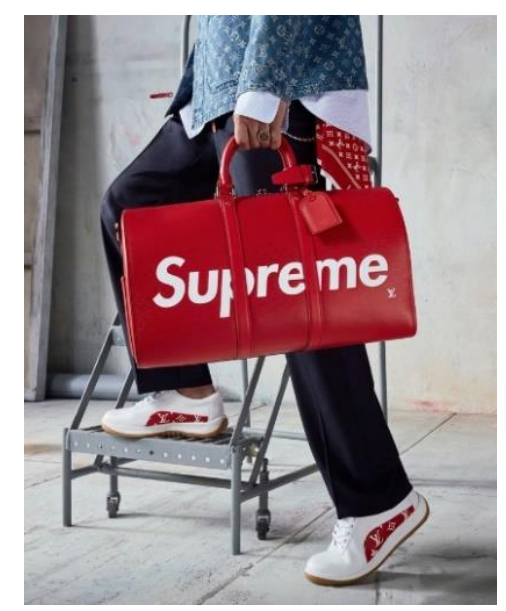

Figure 13. Louis Vuitton x Supreme Collection 


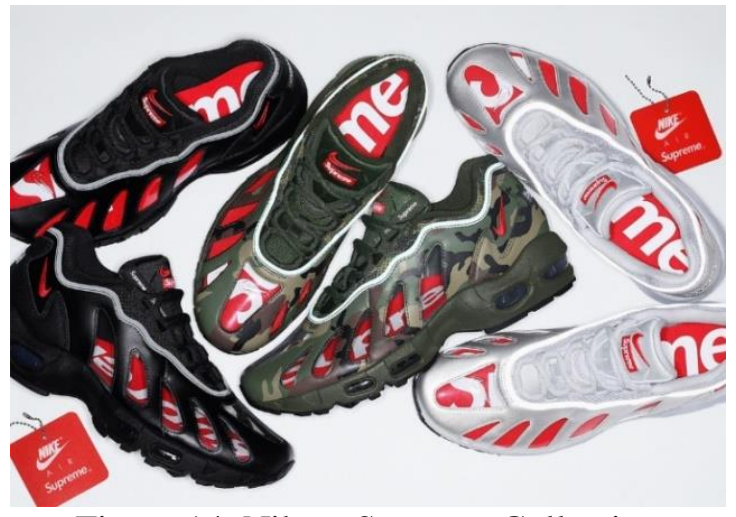

Figure 14. Nike x Supreme Collection

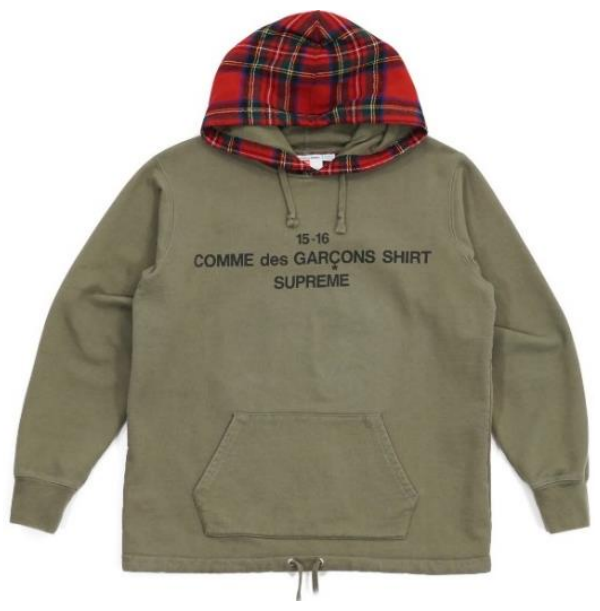

Figure 14. Supreme x Commes De Garcon Collection

Supreme first collaborated with Sarcastic as early as 1998, only four years after its founding. Moreover, its list of collaborations is composed of well-established brands. Those brands have been around much longer than Supreme, and their consumers are loyal. Therefore, it is safe to assume that Supreme piggybacked on its collaborators in widening its name to the consumers of said collaborators.

Aside from fashion brands, Supreme also collaborates with food and beverage brands. It released a cookie with Oreo and a bottled drink with HydraPak. In 2020, Supreme released lipstick in collaboration with a makeup brand, Pat McGrath. By collaborating with these brands, Supreme broadens its recognition beyond the fashion people, as well as exceeding age, gender, domicile and interest.
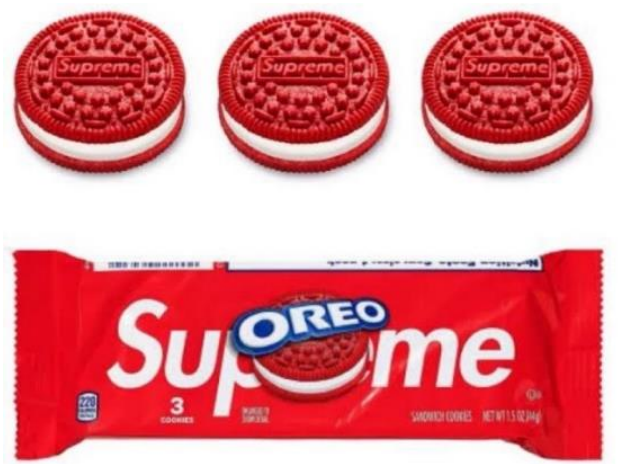

Figure 15. Supreme x Oreo Collaboration
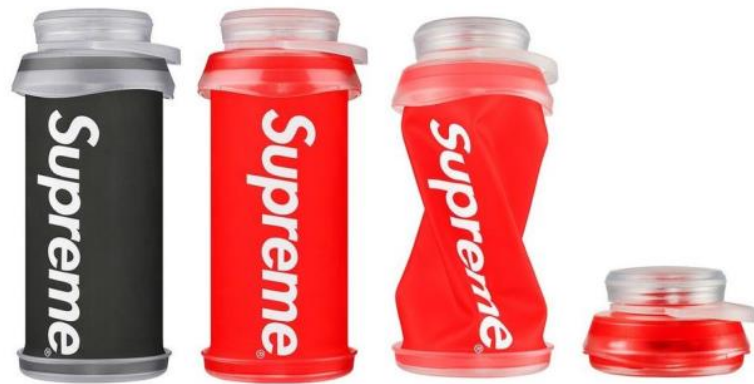

Figure 16. Supreme x HydraPak Collaboration

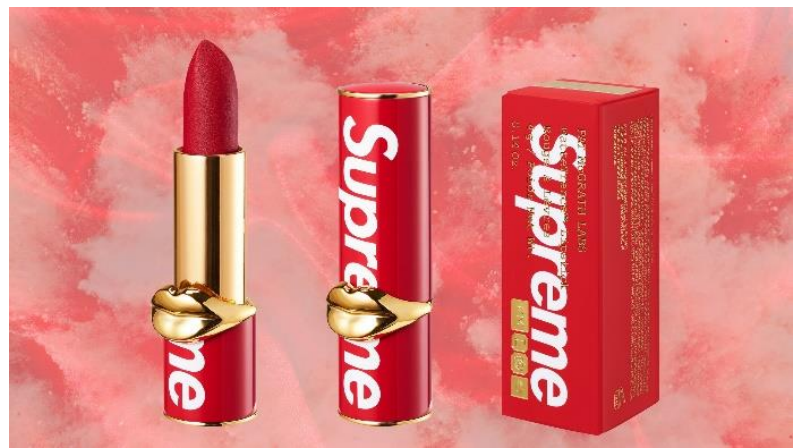

Figure 17. Supreme x Pat McGrath

From the brand's track record, it can be understood that Supreme's products are purposefully difficult to get ahold of. This strategy thus makes their products to be in high demand. Its collaboration products are even harder to grab. The unfulfilled demand of the consumers results in the resale practice. 
Consumers queuing for Supreme products are actually buying to be sold again. Those who do not get the products from Supreme directly can buy from the resellers. Meanwhile, those who do can resell for an inflated price.

Supreme resell has become a lucrative business. As an instance is a 21-year old Londoner, Lydia Clear. Clear "spent a total of $£ 300$ on hoodies and T-shirts and made a profit of $£ 1,000$ ”. Starting when she was only 15 years old, "she spends about two hours a day reselling, and makes about $£ 1,000$ profit every month" (Bearne, 2017). To list a few of renowned buy-and-sell websites are Strictlypreme, StockX, Grailed, Dedop and a Facebook group called The 444Basement.

Supreme's approach in limiting the number of products it sells and enticing other brands to collaborate builds anticipation among its consumers. They are even willing to spend more money than what Supreme originally sells for. This eagerness creates a resell industry in itself. Its products are not only considered as a piece of clothing and accessory, but also have become collectors' items.

\section{CONCLUSION}

The impact of globalization in the last 20 years has dramatically disrupted the production, distribution and marketing sides of the fashion industry. In order to succeed, fashion brands must continually adapt to the ever-changing innovations globalization brings. A brand that has been successfully growing in the past two decades is Supreme. The brand has gone to amass a cult-like following around the world, while at the same time created a high-end streetwear image.
After careful observation of the brand's history via its website and social media, it can be concluded that three approaches help Supreme rising as a global phenomenon. The first approach is by commodifying the African-American community. It uses characteristics of African-American culture in its products, e.g., oversized clothes. The second approach is by using celebrity endorsement. The oversized clothes it releases are then worn by African-American hip-hop stars, notably Kanye West, to be posted on their social media platforms.

The last but not least approach is releasing a limited amount of products, either by itself or by collaborating with other brands. It results in the hype around the brand every time it releases a new collection. The combination of these approaches keeps the price of its products high and the consumers devotedly admiring.

\section{REFERENCES}

Adhitya, G. N. \& N. Wulandari. (2020). Colonial remains in Indonesian Fashion blogipelago. Journal of Language and Literature. 20(2), 181-198. https://ejournal.usd.ac.id/index.php/JOLL/arti cle/view/2611/pdf.

Barker, C. (2004). Cultural studies teori dan praktik. Kreasi Wacana.

Bearne, S. (2017). Meet the teens making thousands from selling online. The Guardian.

https://www.theguardian.com/fashion/ 2017/oct/23/teens-selling-online-depopebay.

Beltran, S. (2018). What is a 'hypebeast' and where do you find them?. Esquirime. https://www.esquireme.com/content/26 947-what-is-a-hypebeast-and-wheredo-we-find-them. 
Brewer, T. (2021). How to get the skater style. The Trend Spotter. https://www.thetrendspotter.net/skate r-style-outfits/.

Clifton, J. (2016). Why are so many people obsessed with Supreme?. Vice. https://www.vice.com/en/article/5ga39 3/supreme-and-the-psychology-ofbrand-devotion.

Cochrane, L. (2017). How street-styled restyled the world - from Hip-hop to Supreme and palace. The Guardian. https://www.theguardian.com/fashion/ 2017/mar/29/how-streetwear-styledthe-world-from-Hip-hop-to-supremeand-palace.

Federal Trade Commission. (2009). Guides concerning the use of endorsement and testimonial guides. Federal Trade Commission.

https://www.ftc.gov/sites/default/files/a ttachments/press-releases/ftcpublishes-final-guides-governingendorsements-

testimonials/091005revisedendorsemen tguides.pdf.

Fiske, J. (1990). Cultural studies: Ethnography and everyday life (Volume 4, number 1). Routledge.

Giddens, A. (1990). The consequences of modernity. Stanford University Press.

Grusky, D.B. (2014). Social stratification: Class, race, and gender in sociological perspective (4th edition). Westview Press.

Hills, M. C. (2020). The $\$ 8$ Supreme Oreo is being resold for 2000 times the price on eBay. Evening Standard. https://www.standard.co.uk/insider/liv ing/the-8-supreme-oreo-is-beingresold-for-2000-times-the-price-onebay-a4368281.html.

Huddleston, T. (2019). How Supreme Went from a Small NYC Skateboard Shop to a $\$ 1$ Billion Global Phenomenon. CNBC. https://www.cnbc.com/2019/10/10/how -supreme-went-from-small-nycskateboard-shop-to-a-globalphenomenon.html.

Ho, H. (2019). Top 10 fashion brands of 2019. Hypebeast.

https://hypebeast.com/2019/12/bestfashion-clothing-brands-designersupreme-louis-vuitton-nike.

Hoffman, D. (2021). The business of hype: How to master the drop. Coremedia. https://blog.coremedia.com/blog/thebusiness-of-hype-how-to-master-thedrop.

Holmes, K. (2016). Cultural appreciation v. cultural appropriation: Why it matters. Green Heart.

https://greenheart.org/blog/greenheart -international/cultural-appreciationvs-cultural-appropriation-why-itmatters/.

Houston, J. \& N. Fennell. (2021). How Supreme went from a small skateboarding store to a billion-dollar streetwear company. Business Insider. https://www.businessinsider.com/supr eme-fashion-brand-so-expensive-viralskateboarding-2019-5?amp.

Jenkins, E. Z. (2010). Commodity/ commodification and cultural studies. In R. Michael, et al. (Eds.) The encyclopedia of literary and cultural theory (Wiley-Blackwell encyclopedia of literature) (pp. 965-970). John Wiley \& Sons.

Mahadevan, T. (2021). Supreme is Opening Its Milan, Italy Store on 6 May. Complex. https://www.complex.com/style/supre me-opening-milan-italy-store-may-6.

Mann, M. (2013). The sources of social power (Volume IV). University Press.

Mansell, S. F. (2013). Capitalism, corporation and social contract. University Press.

Mayhew, S. (2009). A dictionary of geography. University Press. 
Mikhaylov, A. (2016). Why is Supreme always sold out. Medium. https://medium.com/@ antonmikhaylo v/why-is-supreme-always-sold-out17bdf782a47.

O’Brien, G. (2009). James Jebbia is Supreme. interview.

https://www.interviewmagazine.com/f ashion/james-jebbia-is-supreme.

Radcliffe, L. \& Andolina. (2002). Transnat. Communities Prog. Seminar.

Safril, M. A. (2015). Isu-isu globalisasi kontemporer. Graha Ilmu.

Schiffer, J. (2017). The Kanye West effect: Why Hip=Hop fashion is on the rise. Glossy. https://www.glossy.co/rise-ofstreetwear/why-rapper-brandedfashion-is-on-the-rise/.

Sullivan, R. (2017). Charting the rise of Supreme, from cult skate shop to fashion superpower. Vogue.

https://www.vogue.com/article/historyof-supreme-skate-clothing-brand.

Supreme [@supremenewyork]. Instagram. https://www.instagram.com/supremen ewyork/.

Supreme. Website. https://www.supremenewyork.com/.

Sztompka, P. (2007). Sosiologi perubahan sosial. Prenada Media Group.

Takanashi, L. (2020). Supreme team: The story behind the brand's original design crew.

Complex. https://amp.www.complex.com/style/h ow-supreme-brand-came-to-be.

UKEssays. (2018). Impact of globalization on fashion and pharmaceutical industries economics essay. UKEssays. https://www.ukessays.com/essays/econ omics/impact-of-globalization-onfashion-and-pharmaceuticalindustries-economicsessay.php?vref $=1$.
Waldinger, R. \& D. Fitzgerald. (2004). Transnationalism in question. Research Gate. University of California.

Wilson, R. (2018). Here's every clothing brand Supreme has collaborated with. Highsnobiety.

https://www.highsnobiety.com/p/supre me-clothing-brand-collaboration-list/.

Yin, R.K. (1999). Case study research: Design and method. SAGE Publications AsiaPacific. 